DOI: https://doi.org/10.34069/AI/2021.46.10.15

How to Cite:

Vasylynchuk, V., Kovalenko, V., Nekrasov, V., Kopan, O., \& Shchupakivskyi, R. (2021). Forensic prevention of crimes in criminal investigation techniques. Amazonia Investiga, 10(46), 162-168. https://doi.org/10.34069/AI/2021.46.10.15

\title{
Forensic prevention of crimes in criminal investigation techniques
}

\section{Криміналістичне запобігання в методиці розслідування кримінальних правопорушень}

Received: September 18, 2021
Accepted: November 1, 2021

\author{
Written by: \\ Vasylynchuk Viktor ${ }^{56}$ \\ https://orcid.org/0000-0001-5415-8450 \\ Kovalenko Valentyn ${ }^{57}$ \\ https://orcid.org/0000-0002-2041-250X \\ Nekrasov Viacheslav ${ }^{58}$ \\ https://orcid.org/0000-0002-7529-7270 \\ Kopan Oleksii ${ }^{59}$ \\ https://orcid.org/0000-0002-0797-7952 \\ Shchupakivskyi Roman ${ }^{60}$ \\ https://orcid.org/0000-0002-2036-0332
}

\begin{abstract}
The purpose of the article is to determine the place and role of forensic prevention in the structure of methods of investigation of certain types of crimes. The subject of research is the concept and features of forensic prevention. The research methodology includes general scientific and special methods of legal science: historical and legal method; structural and functional method; system and structural method, logical and semantic analysis method, formal and legal analysis method. Research results. The issues related to the characteristics of forensic crime prevention are considered. Different points of view on the role, significance and structure of forensic crime prevention are summarized and the conclusion that this legal institution is an integral part of forensic science is made. Practical implementation. The main methods and means of forensic prevention of criminal offenses are determined. Value / originality. It is concluded that the prevention of crimes should be aimed at neutralizing and eliminating the causes that contribute to their commission, and
\end{abstract}

\begin{abstract}
Анотація
Метою статті $\epsilon$ визначення місця і ролі криміналістичної профілактики в структурі методики розслідування окремих видів злочинів. Предметом дослідження є поняття та особливості криміналістичної профілактики. Методологія дослідження включає загальнонаукові та спеціальні методи юридичної науки: історико-правовий метод; структурно-функціональний метод; системно-структурний метод, метод логікосемантичного аналізу, метод формальноправового аналізу. Результати дослідження. Розглянуто питання, пов'язані iз характеристикою криміналістичної профілактики злочинів. Узагальнюються різні точки зору на роль, значення та структуру криміналістичної профілактики злочинів та робиться висновок, що даний правовий інститут є невід'ємною частиною криміналістичної науки. Практичне значення. Визначено основні методи та засоби криміналістичної профілактики кримінальних правопорушень. Цінність / оригінальність. Зроблдено висновок, що
\end{abstract}

\footnotetext{
${ }^{56}$ Doctor of Law, Professor, Professor of the Department of Search and Investigation Activities of the National Academy of Internal Affairs, Ukraine.

${ }^{57}$ Doctor of Law, Professor, Leading Researcher of the Laboratory of Copyright and Information Technologies of the Research Center for Forensic Science on Intellectual Property of the Ministry of Justice of Ukraine, Honored Lawyer of Ukraine, Corresponding Member of the National Academy of Legal Sciences of Ukraine.

${ }^{58} \mathrm{PhD}$ in Law, Associate Professor, Professor of Criminology and Penal Law of the National Academy of Internal Affairs, Ukraine.

${ }^{59}$ Doctor of Law, Professor, Leading Researcher of the Scientific Laboratory on Crime Prevention of the National Academy of Internal Affairs, Ukraine.

${ }^{60}$ Doctor of Law, Senior Research Fellow of the Scientific Institute of Public Law, Ukraine.
} 


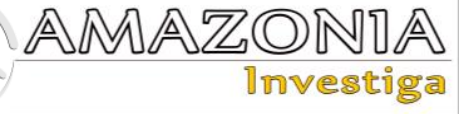

the pre-trial investigation authorities should play the key role in this process.

Keywords: forensic prevention, forensics, prevention, warning, termination, crime, forensic science.

\section{Introduction}

The fight against crime in Ukraine is an important state task at the present stage of building the rule of law. Crime prevention is one of the directions of this fight. The decisive role in the prevention of criminal offenses is assigned to the bodies of the National Police of Ukraine, which have the appropriate powers, forces and means.

In the present context, based on the scientific theory of the law in unity with the advanced practice, they are designed to solve this problem in a new way. Therefore, the solution of an important national task - crime prevention largely depends on the scientific and methodological support of this branch of their activity.

The process of research and improvement of scientific and practical knowledge of forensic prevention of criminal offenses has faced a number of theoretical problems related to determining the nature of this phenomenon, the formation of conceptual and terminological apparatus since the time of its acceptance as a special assignment in forensic science. It is clear that their correct solution would greatly contribute to the effective application of the provisions on the prevention of criminal offenses.

In addition, it should be noted that the problem of crime prevention has long been of a dogmatic nature, which is to some extent reflected in the existing concepts in domestic forensic science, research, provisions. Besides, the role of forensic science in the system of prevention of antisocial manifestations is still insufficiently defined. Only certain aspects of this problem are reflected in the relevant forensic literature.

The urgency of this problem is also due to the trends of new ways and methods of committing criminal offenses, which, in turn, is a matter of serious concern to both the State and society. профілактика злочинів має бути спрямована на нейтралізацію i усунення причин, що сприяють їх вчиненню, а особливу роль в даному процесі відіграють саме органи досудового розслідування.

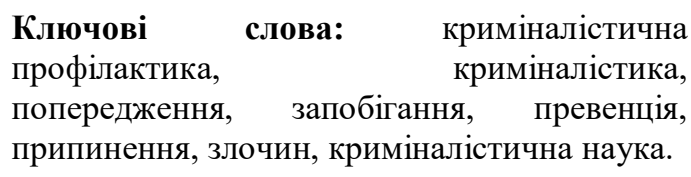

Since scientific and technological progress does not stand still, criminal activity changes along with it. Therefore, the scientific and theoretical and practical significance of determining the place and role of forensic crime prevention, its methods and tools under modern conditions is of significant scientific interest and requires an indepth and thorough study.

Thus the purpose of the article is to determine the place and role of forensic prevention in the structure of methods of investigation of certain types of crimes.

\section{Methodology}

The methodological basis for the research is the complex use of the set of methods and techniques of modern theory of scientific knowledge of social and legal phenomena, which provides an opportunity to explore the problem in the unity of its content and legal form, to carry out systematic analysis of preventive activities in general and law enforcement agencies in particular.

Thus, historical and legal method is used to reveal the features of the concept and scientific foundations of the doctrine of forensic prevention.

Structural and functional method allowed to determine the patterns and trends in the development of prevention by means and methods of criminology.

The application of the system and structural method made it possible to classify the tasks, methods of forensic prevention and to determine the current levels, forms and directions of preventive activities.

With the help of logical and semantic analysis method the conceptual apparatus on the issue under consideration is specified. 
Formal and legal analysis method allows to identify the place of crime prevention in criminal investigation techniques.

\section{Literature Review}

The term "prevention" means a set of preventive measures aimed at maintaining and strengthening the normal state of order (Ozhehov, 2004, p. 345).

The terms "warning", "termination", "prophylaxis" (which are often considered synonymous) are used along with the concept of "prevention" in the legal literature, regulations and practical activities of law enforcement agencies. Various legal sciences are engaged in research of crime prevention, and first of all sciences of a criminal law cycle, in particular, criminal law, criminology, criminal procedural law, forensics. The comprehensive approach to the analysis of crime prevention allows to identify the features, structure and other characteristics of this legal category.

As Frank (2006) correctly point out crime prevention has always been a difficult concept. Much of its opaque nature derives from the difficulties presented by the idea of crime itself, and the range of theoretical and conceptual disputes that permeate its study.

According to the definition provided by the National Council for Crime Prevention (2021) crime prevention refers to a broad set of longterm activities taken to reduce the risk of crimes, disruptive behaviour and becoming a victim of crime. These activities may be carried out by a range of actors, such as authorities, businesses, non-governmental organisations and residents.

Welsh and Farrington (2012) state that preventive measures can be manifested both in the form of crime control or repression and (more often) in the efforts to prevent crime or criminal offending in the first instance-before the act has been committed.

Sutton, Cherney, White and Clancey (2021) claim in their work that the combination of social and situational/environmental crime prevention strategies as more effective alternatives to policing, criminal justice and 'law and order' approaches.

Nevisi (2019) outlines 16 types of crime prevention (primary, secondary, thertiary, shortterm, long-term, social, developmental, shame, active, non-penal, penal, judicial, disciplinary, common, special, situational) and provides the description of each of these types.

Criminal law science carries out prevention, obtained by criminal establishment and application of punishment for committing illegal acts, thereby influencing the behavior of an individual, the formation of a stable attitude to law-abiding behavior (Naumov, 2011, p. 6).

Vasylchenko (2006, p. 12), stressing on the special role of criminal law, notes that "the potential of this branch of law is manifested in criminal law relations, while providing educational, warning effect in the form of general or special prevention".

In addition, Zharikov (2009, p. 15) emphasizes that the criminal law influence is associated with the implementation of its preventive and educational functions.

\section{Results and Discussion}

Criminology considers crime prevention as the set of special measures aimed at identifying the causes and conditions of crimes, taking measures to neutralize and eliminate them (general prevention), as well as identifying persons who can be expected to commit crimes, as well as their registration and conducting within the framework of these records the necessary individual preventive work with such persons (individual prevention) (Inshakov \& Symonenko, 2012, pp. 183 - 184).

Criminal procedural prevention is the system of preventive forms (measures) regulated by the criminal procedural law, as well as by-laws, implemented within pre-trial and judicial proceedings by State bodies and officials with the authority to implement it, as well as other participants in criminal proceedings, members of the public in the process of identifying the circumstances that contributed to the crime, preventive work with the suspect (accused, defendant), victim and the promotion of lawabiding behavior and legal education to eliminate opportunities for implementation similar and other crimes (Danylova, 2015, p. 127).

Thus, each of the above legal and applied sciences considers different aspects of crime prevention, which allows to reveal the various points of this legal institution.

Meaningful analysis of these sources allows to conclude that crime prevention is the social activity aimed at harmonizing the relations in 


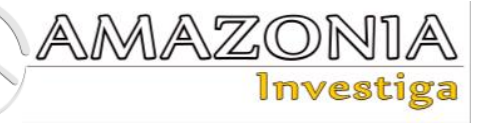

society, the state of which can minimize the causes and conditions that give rise to crimes.

In this regard, Makhtaiev (2001, p. 23) correctly notes that "crime prevention is a special kind of social practice that provides such a transformation of social relations, which eliminates or neutralizes the causes and conditions that contribute to criminal behavior".

Crime prevention is aimed at various objects of preventive influence, and the process of influence is the practice of crime prevention. This process is associated only with public relations, which are violated in connection with certain forms of criminal behavior and the implementation of measures to prevent it. This is the difference between crime prevention as the special type of social practice from social practice of other types (Aleksieiev, 1989, p. 224).

Prevention of crimes along with their detection and investigation is the least costly and most effective way to combat crime as a social phenomenon, as it provides detection and timely elimination of its criminogenic factors and genetic bases. These factors and bases of crimes, noticed in time, are better exposed to the means of prevention, which allows to interrupt the planned or initiated criminal activity in order to prevent criminal outcome.

As for the issue of the nature of forensic crime prevention there are still different approaches to defining the concept of this category in the legal and special forensic literature. In particular, the question arises as to the definition of the concept. Besides, modern criminal procedure legislation, unfortunately, does not contain rules that would regulate crime prevention activities.

Currently, there is no single approach to determining the place of forensic prevention in the structure of forensic science.

Thus, Belkin includes crime prevention in the subject matter of criminology (2009, p. 649). Ishchenko and Ehorov (2010, p. 5) proceed from the fact that forensic prevention, namely the development and improvement of forensic methods and means of crime prevention, should be considered as the specific task of forensics.

Yablokov (2005, p. 121) note that forensic prevention is associated with identifying the causes and conditions of crime, objects of forensic influence, as well as with specific preventive measures complicating the commission of new crimes, and termination or interruption of criminal activity of individuals. In this regard, the above authors distinguish two types of forensic prevention: 1) investigation prevention and 2) forensic prevention.

Zudin (1995, p. 21), analyzing the forensic model of crime prevention, draws attention to the fact that it is the system of operational and tactical, scientific and technical, organizational and educational techniques and means of educational influence to identify the causes and conditions that contributed to the commission of crimes and their elimination on the basis of criminal cases investigated and tried.

Ivanov (2014, p. 15), investigating forensic prevention, notes that it should be considered as one of the independent private theories, which is the system of scientific provisions and practical recommendations on the patterns of development and use of technical means, tactics and techniques in criminal proceedings to prevent conception and prepared crimes, timely detection, prompt, full disclosure and quality investigation of crimes, cessation of specific criminal activity and elimination of its dangerous consequences, detection of circumstances that contributed to the commission and concealment of crimes, overcoming any form of opposition to investigation.

Adelkhanian, Aminov, Fedotov (2017, p. 20) point out prevention is the most promising way to combat crime, as it eliminates the onset of possible socially dangerous consequences of the crime, directly affect the causes and conditions that contribute to the crime. Besides, it is correctly noted that the preventive effect on crimes is based on the fact that the relevant activity activity has the capacity to adjust criminogenic factors in the period at a time when they have not yet entered into force and are therefore easier to neutralize, or block.

Thus, the supporters of the traditional understanding of crime prevention consider the prevention of specific crimes, preventing certain members of society from committing offenses, guilty wrongdoing in a broad sense, and identifying the causes of crimes, conditions and circumstances that contribute to their commission, identification of persons may commit crimes due to their anti-social orientation - the goals of prevention in the narrow sense. However, they believe that, unlike the goals of prevention, the ultimate goal is the complete eradication of crime. 
Domestic criminology enshrine that preventive activities cannot be aimed at the complete eradication of crime. Crime prevention in the broadest sense is the system of economic, political, ideological, cultural, domestic, legal and other social measures. Their practical implementation is aimed at changing the quantitative and qualitative characteristics of criminal manifestations, eliminating mostly common causes and conditions that contribute to the commission of crimes. On this basis, crime prevention is a complex system of social relations, whose content consists of many different elements consisting of blocks which, in their, form the appropriate areas of crime prevention.

There is a reform and improvement of such basic principles as legality, democracy, humanism, justice and science under current conditions of European integration processes in our country, which have an impact on the properties of measures of general social crime prevention.

Legal warning is not only preventive but also enforcement activities - addressing the causes and conditions conducive to the commission of offences it (special prevention of inadmissibility of violations of the law), and to combat them by legal means and means.

Scientific and methodological foundations of forensic crime prevention are the unity of ways and means of studying social objects, causes and conditions that contribute to the commission of specific crimes and other anti-social manifestations related to them, and the development of measures to eliminate and neutralize them.

According to their purpose, conditions and methods of cognition, the methods of forensic crime prevention are of clearly defined, socially valuable nature. They have relative independence and are used only in the context of the functioning of forensic crime prevention, although in some cases they can be borrowed from other social, natural and technical sciences. The methods of forensic crime prevention are complex in their context.

The specificity of methods of forensic crime prevention is based on their relative independence as the system of knowledge with criteria of social and practical value. The effectiveness of forensic means and methods of crime prevention is reflected in the area of law enforcement activities of criminal proceedings and is carried out in the active practice of pre-trial investigation and court. In essence, we are dealing with socio-political practice to the extent that it is necessary to combat crime and related anti-social manifestations. At the same time, the complex nature of forensic means and methods of preventive influence cannot to one or another degree affect various aspects of public life, its economic, political, socio-psychological, cultural and other relations.

The very nature of forensic crime prevention is manifested not only in forensic, but also in criminological and social prevention of antisocial phenomena, which allows to form a single, purposeful socially valuable and effective system of preventive measures. It is clear that the methods of different levels interact in this system - from general theoretical abstract techniques to specific private funds and methods of preventive action used in the practice of preliminary investigation and court.

The peculiarity of the subject matter of forensic crime prevention lies in the complex systematic use of data from natural, technical, and social sciences.

Belkin (2001, pp. 87 - 88) classified the means and methods of crime prevention into:

1) means and methods of establishing the causes and conditions that contributed to the commission or concealment of crimes;

2) means and methods of obtaining information about the planned crimes;

3) means and methods of protection of various objects from criminal encroachments and creating favourable conditions for evidence to emerge.

In turn, forensic tools and methods of establishing the causes and conditions that contributed to the commission or concealment of crimes can be divided into:

1) the means and methods of direct identification by the investigating body and the court;

2) the means and methods of obtaining from the investigating authority or the court indirect information about these causes and conditions;

3 ) the means and methods of expert establishment of these data.

Ivanov (2014, p. 94) proposes the following classification of the methods of forensic crime prevention: 


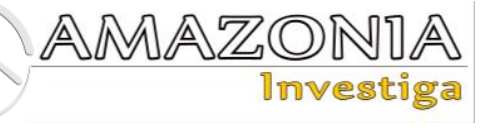

methods of prevention of conceived and prepared crimes;

methods of timely detection of crimes and other objects of forensic preventive influence, detection and initiation of investigative situations of preventive nature;

methods of fast, full disclosure and high-quality investigation of committed crimes;

methods of suppressing specific criminal activities and dealing with their dangerous consequences;

methods of detection and elimination in the process of investgation of circumstances that contribute to the commission and concealment of crimes, overcoming any form of opposition to the investigation.

Forensic crime prevention techniques may also include surveillance, measurement, description, recording by technical means, comparison, experiment. The following sociological methods should play a special role:

a) biographical method and generalization of independent characteristics;

b) interviewing;

c) questionnaires;

d) analysis and generalization of practical experience of law enforcement agencies and courts;

e) analysis of documents and statistical reports of law enforcement agencies and the courts.

Forensic prediction is based on specific sociological studies. In particular, structural and prognostic methods of forensic prevention allow:

to plan the system of means and methods of procedural activity on the basis of the collected material;

to conduct, in a timely and optimal manner, individual investigative actions to collect evidence relating to the causes and conditions that contributed to the commission of particular crime;

to identify patterns of factors that determine antisocial behavior of certain individuals and/or social groups;

to outline socially valuable and effective means and methods of preventive action aimed at normalizing lifestyle.

Proper task setting contributes to the effective implementation of prevention, while they are objectively reduced to the systematic detection and analysis of phenomena, factors and circumstances that contribute to the commission of crimes, clarification and study of contradictions and conflicts that lead to the emergence and implementation of criminal intent, as well as to the development of the offender's identity; continuous identification of persons who can be expected to commit crimes, their examination and active preventive influence on them; elimination or neutralization of phenomena and circumstances (causes and conditions) that contribute to anti-social behavior; criminal development; development and implementation of special tools, techniques and methods that contribute to crime prevention, etc. (Makhtaiev, 2001, p. 27).

\section{Conclusion}

Thus, effective counteraction to crimes involves not only their prompt investigation and detection, identification and prosecution of perpetrators, but also the application of preventive measures. Prevention of crimes should be aimed at neutralizing and eliminating the causes that contribute to their commission; the pre-trial investigation authorities play a special role in this process.

Forensic crime prevention is the system of tools and methods carried out by pre-trial investigation bodies, the main purpose of which is to identify the causes and conditions of criminal activity, as well as submit appropriate proposals and recommendations to eliminate them and prevent future criminal acts.

Thus, in our opinion, forensic crime prevention occupies a decisive place in the system of methods of crime investigation. However, under modern conditions, this activity requires, firstly, the legal consolidation, and secondly, the definition of the methods and means of preventive activities.

The use of forensic and other specialized knowledge, in particular forensic techniques, has outgrown the context of the criminal process. If the means and methods of forensic techniques are applied to prevent and detect crimes outside the framework of criminal procedure, they do not lose their forensic character, just the conditions and tactics of their practical use change. In our opinion, these changes in the use of forensic data over time will be reflected in the definition of the subject of forensics, the actual content of which has been constantly changing recently. There is a process of expanding the scope of criminology through the actual development of this science not only issues of investigation and detection of crimes, but also their prevention. 


\section{Bibliographic References}

Adelkhanian, R., Aminov, D., and Fedotov, P. (2017). Criminalistics. Course of lectures: textbook. Moscow: Unity-Dana. https://www.iprbookshop.ru/71096.html

Aleksieiev, A., ed. (1989). Criminology and crime prevention: a textbook. Moscow: Publishing House of MVShM MVS USSR.

Belkin, R. (2001). Course of criminology: textbook. 3rd Edition. Moscow: UNITIDANA, Law and Legality. https://www.twirpx.com/file/950107/

Belkin, R. (2009). Selected works. Moscow: Norma. https://www.twirpx.com/file/1603148/

Danylova, S. (2015). The concept and essence of criminal procedure prevention. Forensic Library, No. 1.

Frank, C. (2006). Crime prevention: definitions and debates. C. Frank, Monograph No 126: The Role of Education, Health and Social Development in Preventing Crime. Institute for security studies. https://issafrica.org/chapter-2-crimeprevention-definitions-and-debates

Inshakov, S. \& Symonenko, A., eds. (2012). Criminology: a textbook. Moscow: UnityDana; Law and Justice.

Ishchenko, E. and Ehorov, V. (2010). Forensics for investigators and investigators: a scientific and practical guide. Moscow: INFRA-M-CONTRACT.

Ivanov, I. (2014). Forensic crime prevention: methodological principles and distinction from other crime prevention subsystems. Bulletin of criminology, Issue 3, No. 51.

Makhtaiev, M. (2001). Fundamentals of the theory of forensic crime prevention: a monograph. Moscow: Raritet, 2001.

National Council for Crime Prevention (2021). Crime prevention activities. https://rikoksentorjunta.fi/en/crimeprevention-activities

Naumov, A. (2011). Russian criminal law: a course of lectures in 3 volumes. Vol. 1:
General Part. Moscow: Walters Kluwer. https://www.twirpx.com/file/2536896/

Nevisi, H. M. (2019). 16 types of crime prevention. Journal of Forensic Sciences and Criminal Investigation, No. 3(1), p. 1018. https://www.jsmcentral.org/smforensic/fulltext_smjfrc-v3-1018.pdf

Ozhehov, S. (2004). Dictionary of the Russian language. Moscow: "ONIX 21st century", "World and Education". http://cyberlan.com.ua/wpcontent/uploads/2015/07/Tolkovij-slovarjrusskogo-yazika.pdf

Sutton, A., Cherney, A., White, R. and Clancey, G. (2021). Crime Prevention: Principles, Perspectives and Practices. 3rd Edition. Cambridge: Cambridge University Press.

Vasylchenko, O. (2006). Interrelation between criminal and legal and criminal and procedural relations: monograph. Moscow: Os-89.

Welsh, B. C. and Farrington, D. P. (2012). Crime Prevention and Public Policy. The Oxford Handbook of Crime Prevention. DOI: 10.1093/oxfordhb/9780195398823.013.0001 https://www.oxfordhandbooks.com/view/10. 1093/oxfordhb/9780195398823.001.0001/ox fordhb-9780195398823-e-1

Yablokov, N., ed. (2005). Forensics: a textbook. Moscow: MAUP. http://koldin-msu.ru/wpcontent/uploads/2015/03/\%D0\%A3\%D1\%8 7\%D0\%B5\%D0\%B1\%D0\%BD\%D0\%B8\% D0\%BA-

$\% \mathrm{D} 0 \% \mathrm{BA} \% \mathrm{D} 0 \% \mathrm{BB} \% \mathrm{D} 0 \% \mathrm{~B} 0 \% \mathrm{D} 1 \% 81 \% \mathrm{D}$ $1 \% 81 \% \mathrm{D} 0 \% \mathrm{~B} 8 \% \mathrm{D} 1 \% 87 \% \mathrm{D} 0 \% \mathrm{~B} 5 \% \mathrm{D} 1 \% 8$ $1 \%$ D0\%BA\%D0\%B8\%D0\%B9-2005.pdf

Zharikov, Yu. (2009). Criminal and legal influence and the mechanism of its realization: monograph. Moscow: Publishing House "Jurisprudence".

Zudin, V. (1995). Forensic crime prevention (concept, principles, means of implementation): textbook. Voronezh: Publishing House of Voronezh University. 